\title{
PENGEMBANGAN IHDN DENPASAR MENJADI UNIVERSITAS HINDU NEGERI MODERN MELALUI PENINGKATAN KOMPETENSI PROFESIONAL DOSEN
}

\author{
Oleh \\ I Ketut Gunarta \\ Dosen pada Fakultas Brahma Widya IHDN Denpasar
}

\begin{abstract}
Developing IHDN Denpasar to be the State Hindu University has been the aspiration of the Hindu people in Indonesia. The development should be realized through developing the quality of the professionalism of the lecturer. It plays significant role in improving the quality of the education. A lecturer is required to have a pedagogic competence, which is the skill of teaching, a personality, which includes character and maturity, a professional skill, which refers to the mastery of content and methods of teaching, and social skill, which is the ability in making interaction with students and people.
\end{abstract}

Key words : developing IHDN Denpasar, lecturer competence, professional

\section{PENDAHULUAN}

Pengembangan IHDN Denpasar meningkatkan statusnya menjadi Universitas Hindu Negeri yang Modern muncul saat ini merupakan keinginan adanya perguruan tinggi Hindu yang menyesuaikan diri dengan tuntutan pasar atau perkembangan kehidupan sosial ekonomi nasional maupun global. Pengembangan IHDN Denpasar tidaklah berhenti, melainkan terus berusaha untuk mengembangkan diri. Pengembangan diri ini dilakukan dengan pembukaan program studi baru, pembukaan jurusan dan fakultas baru, serta membuka kesempatan seluas-luasya bagi berkembangnya berbagai macam disiplin ilmu pengetahuan namun tetap berlandaskan agama Hindu.

Pengembangan IHDN Denpasar menjadi Universitas Hindu Negeri yang modern tentunya didukung oleh banyak faktor, baik faktor dalam dan faktor luar. Seperti tenaga pengajar/dosen yang kualified, tenaga administrasi yang cakap dan tanggap, fasilitas gedung yang memadai, fasilitas perpustakaan yang lengkap, pelayanan akademik dan kemahasiswaan yang tertib dan yang lainnya. Faktor tenaga pengajar/dosen yang memiliki kompetensi profesional merupakan salah satu faktor pendukung dalam pengembangan IHDN Denpasar. Oleh karenanya, peningkatan kompetensi profesional dosen merupakan hal yang menarik dalam kaitan dengan dinamika pendidikan dan kependidikan hubungannya dengan pengambangan kualitas perguruan tinggi agama Hindu yakni pengembangan IHDN Denpasar menjadi Universitas Hindu Negeri yang Modern.
Berkenaan dengan topik bahasan ini, maka ada baiknya dijelaskan mengenai apa itu peningkatan, kompetensi, profesional, dosen, kualitas, dan pendidikan tinggi. Peningkatan adalah proses, perbuatan, cara meningkatkan, (usaha, kegiatan, dsb.) (Tim Penyusun, 1994:1060). Kompetensi adalah seperangkat pengetahuan, keterampilan, dan perilaku yang harus dimiliki, dihayati, dan dikuasai oleh guru atau dosen dalam melaksanakan tugas keprofesionalan (UU Guru dan Dosen, 2005:4). Profesional adalah pekerjaan atau kegiatan yang dilakukan oleh seseorang dan menjadi sumber penghasilan kehidupan yang memerlukan keahlian, kemahiran, atau kecakapan yang memenuhi standar mutu atau norma tertentu serta memerlukan pendidikan profesi (UU Guru dan Dosen, 2005:3). Dosen adalah pendidik profesional dan ilmuwan dengan tugas utama mentransformasikan, mengembangkan, dan menyebarluaskan ilmu pengetahuan, teknologi, dan seni melalui pendidikan, penelitian, dan pengabdian kepada masyarakat (UU Guru dan Dosen, 2005:3).

Kata kualitas maksudnya adalah 1. tingkat baik buruknya sesuatu; kadar; 2 . derajat atau taraf (kepandaian, kecakapan, dan sebagainya), mutu (Tim Penyusun, 1994:533). Kemudian dalam UU Sisdiknas 20/2003 pasal 19 (Anonim, 2004:12-13) dijelaskan tentang "pendidikan tinggi merupakan jenjang pendidikan setelah pendidikan menengah yang mencakup program pendidikan diploma, sarjana, magister, spesialis, dan doktor yang diselenggarakan oleh perguruan tinggi". Peningkatan kompetensi profesional dosen dalam hal ini adalah kaitannya 
dengan potensi manusia Hindu yang mampu menjadi pengembang mutu insan-insan atau generasi muda Hindu yang handal dan bertanggung jawab melalui jalur pendidikan tinggi agama Hindu. Jadi dapat ditegaskan bahwa maksud topik ini adalah bagaimana usaha untuk meningkatkan mutu profesi/ pekerjaan atau keterampilan dosen dalam pengembangan perguruan tinggi agama Hindu untuk dapat terwujudnya mutu sumber daya manusia Hindu.

\section{PEMBAHASAN}

\subsection{Sekilas Perjalanan IHDN Denpasar menuju} Universitas Hindu Negeri Modern

Pelaksanaan pendidikan agama Hindu pada jenjang pendidikan dasar, menengah, dan pendidikan tinggi pada awalnya masih tegolong terbatas sekali, dengan adanya berbagai kendala seperti pengakuan sahnya agama Hindu oleh pemerintah RI, sekolah agama Hindu belum ada, tenaga pengajar agama Hindu secara formal belum ada, dan masih banyak lagi kendala yang dihadapi umat Hindu dalam melaksanakan pendidikan agama Hindu di sekolahsekolah di Bali khususnya dan di beberapa wilayah lainnya di Indonesia umumnya.

Awalnya bahwa pendidikan agama Hindu baru terlaksana berkat partisipasi para tokoh/pemuka agama Hindu melalui lembaga swadaya masyarakat di beberapa daerah di Bali. Baru setelah tahun 1953 adanya rintisan oleh Yayasan Dwijendra untuk membidani sekolah yang bernafaskan pendidikan agama Hindu bernama SMP Dwijendra, juga pada tahun 1959 dirintis sekolah Pendidikan Guru Agama Atas Hindu Bali Dwijendra. Khusus untuk perencanaan tentang pelaksanaan pendidikan agama Hindu di sekolah-sekolah, terutama di SD, SMP, dan SMA telah direncanakan secara matang dalam rapat tertanggal 22 Juni 1959 bertempat di Yayasan Dwijendra Denpasar, saat itu rapat dipimpin oleh Bapak I Putu Serangan selaku Kepala Dinas Agama Otonom Daerah Bali. Selanjutnya didirikan pula perguruan tinggi agama Hindu yang bernama Institut Hindu Dharma sekitar tahun 1962. Baru sekitar tahun 1967 ada penegerian PGAAHB menjadi PGAHN Denpasar. Untuk di Bali utara ada PGAHN Singaraja dan di Lombok ada PGAHN Mataram.

Partisipasi masyarakat terhadap pentingnya pendidikan agama Hindu bagi umat Hindu di Indonesia ditandai dengan berdirinya beberapa sekolah guru agama Hindu, seperti : PGA Hindu Sila Dharma Penatahan-Penebel, PGA Hindu Darsana Tabanan, PGA Hindu Saraswati Bajera, PGA Hindu Amlapura, PGA Hindu Klaten, PGA Hindu Lampung, PGA Hindu Saraswati Tolai-Parigi, Sulawesi Tengah,
PGA Hindu Blitar, dan PGA Hindu Tampung Penyang Palangka Raya, Kalimantan Tengah.

Dengan hadirnya UU Pendidikan no. 2 tahun 1989, akhirnya PGAHN Denpasar lenyap dari eksistensinya, karena seorang guru agama Hindu tidak lagi berbasis ijazah setara PGAHN, tetapi minimal berijazah Dilpoma dua (D2), atau diploma 3 (D3). Dengan alasan itu maka tahun 1993 berdirilah Akademi Pendidikan Guru Agama Hindu Negeri (APGAHN) Denpasar, sesuai SK Menag RI No. 58 B/1993, tanggal 27 Februari 1993, yang diresmikan oleh Menag RI dr. H. Tarmizi Taher, pada hari Selasa, 25 Mei 1993. Program yang dibuka di APGAHN Denpasar adalah jurusan Pendidikan Agama Hindu diploma dua (D2) dan diploma tiga (D3). Kehadiran APGAHN Denpasar tidak memberikan kontribusi yang sempurna bagi dinamika pendidikan agama Hindu di Indonesia, oleh karena kebutuhan guru agama Hindu di SMP, SMA dan dosen Hindu di berbagai perguruan tinggi agama dan umum baik negeri dan swasta belum ada yang memiliki kualifikasi untuk persyaratan setidaknya adalah yang berkualifisikasi sarjana (S1) dari tamatan perguruan tinggi agama Hindu negeri.

Dengan berbekal tekad yang bulat oleh para tokoh Hindu dan segenap umat Hindu Indonesia, maka perjuangan mewujudkan perguruan tinggi agama Hindu negeri tetap dilanjutkan. Akhirnya pada tahun 1999 membuahkan hasil yakni dengan meningkatknya status APGAHN Denpasar menjadi Sekolah Tinggi Agama Hindu Negeri (STAHN) Denpasar dengan Kepres No. 20/1999, tertanggal 3 Maret 1999, dan SK Menag RI No. 65 dan 66/1999, tertanggal 16 Maret 1999, yang diresmikan oleh Menag RI Prof. Drs. H.A. Malik Fadjar,M.Sc. hari Sabtu, 10 April 1999. Kehadiran STAHN Denpasar dengan membuka jurusan Pendidikan Agama Hindu jenjang D2, D3, dan S1. Juga dibuka jurusan Hukum Agama Hindu jenjang S1 dan jurusan filsafat Hindu jenjang S1. Kemudian untuk memenuhi kebutuhan kualifikasi dosen agama Hindu di berbagai perguruan tinggi negeri dan swasta, maka STAHN Denpasar sejak tahun 2001 membuka Program Pascasarjana terutama Program Studi Magister (S2) Ilmu Agama Brahma Widya dan pada tahun 2004 membuka Program Studi Magister (S2) Ilmu Pendidikan Agama Hindu.

Kehadiran STAHN Denpasar dirasakan telah memberikan kontribusi yang memadai dalam dinamika pendidikan agama Hindu Indonesia, namun demikian dinamika ilmu pengetahuan, teknologi, dan seni saat ini dan di masa depan perlu diimbangi lagi dengan institusi pendidikan agama Hindu negeri yang mampu bersaing dalam dunia pendidikan di Indonesia dan 
di internasional. Dengan alasan itu, maka tahun 2004 lahir Penpres No. 1 tahun 2004, tertanggal 8 Nopember 2004, tentang Peningkatan Status STAHN Denpasar menjadi Institut Hindu Dharma Negeri (IHDN) Denpasar, yang diresmikan oleh Menag RI Muhammad M.Basyuni, pada hari Rabu, 23 Maret 2005, di kampus pusat Jalan Nusantara-Kubu-Bangli. Program studi yang dibuka di IHDN Denpasar adalah Prodi Pendidikan Agama Hindu dan Prodi Pendidikan Bahasa Bali pada Fakultas Dharma Acarya. Prodi Hukum Hindu, Prodi Penerangan Hindu dan Prodi Pemandu Wisata pada Fakultas Dharma Duta. Prodi Filsafat Hindu, Prodi Teologi Hindu, dan Prodi Manggala Upacara pada Fakultas Brahma Widya. Sedangkan Prodi Magister Ilmu Agama (Brahma Widya) dan Prodi Magister Ilmu Pendidikan Agama Hindu pada Program Pascasarjana. Seiring berjalannya waktu kini IHDN Denpasar bersiap untuk meningkatkan statusnya menjadi Universitas Hindu Negeri Modern dan bersaing secara global dengan membuka program studi baru, jurusan dan fakultas baru.

\subsection{Kompetensi Profesional Dosen}

Perkembangan pendidikan di Indonesia sejalan dengan dinamika tuntutan dan kebutuhan masyarakat itu sendiri. Demikian pula mengenai pelaksanaan pendidikan pada berbagai jenjang juga mengalami kemajuan yang searah dengan kebijakan yang telah ditetapkan oleh pemerintah. Salah satu kebijakan yang paling anyar adalah dengan diundangkannya tentang undang-undang guru dan dosen nomor 14 tahun 2005, sejak tanggal 6 Desember 2005 lalu. Itu berarti bahwa kesiapan dan kemampuan para tenaga pengajar (dosen) juga terus dikembangkan, baik secara kemandirian maupun secara melembaga. Berkenaan dengan hal itu, salah satunya adalah agar para dosen memiliki keterampilan yang memadai dalam tugasnya.

Dalam paparan ini akan dijelaskan mengenai beberapa kompetensi profesional dosen, antara lain : pertama, keterampilan administrasi pendidikan, kedua, keterampilan menggunakan media pendidikan, ketiga, keterampilan metodik dan didaktik, keempat, keterampilan mengelola kelas, kelima, keterampilan evaluasi pendidikan, keenam, keterampilan memberikan penguatan, dan ketujuh, keterampilan membimbing peserta didik. Ada tujuh keterampilan yang perlu dimiliki oleh seorang dosen untuk meningkatkan keprofesionalannya dalam menjalankan tugasnya. Sekilas uraian tersebut seperti berikut ini.

\section{Keterampilan Administrasi Pendidikan}

Pengajar dituntut untuk memahami dan terampil dalam administrasi pendidikan. Pengajar tidak hanya dituntut terampil dalam mendidik, membimbing, melatih, mengarahkan, dan mengajar peserta didik, tetapi juga dapat mengaktualisasikan keharmonisan dalam pengelolaan pendidikan melalui penguasaan keterampilan di bidang administrasi pendidikan. Oleh karena administrasi pendidikan menyangkut tentang pembaruan pendidikan, formulasi umum tentang administrasi pedidikan. Juga tentang tugas kewajiban administratif yang menyangkut program pendidikan, murid/peserta didik, personil, perkantoran/tata usaha sekolah/kampus, keuangan/ belanja pendidikan, pelayanan, dan hubungan masyarakat. Kemudian mengenai proses administratif yang dimulai dari membuat putusan, perencanaan, mengorganisasikan, mengkomunikasikan, mengkoordinasikan, mengawasi, menilai atau monitoring dan evaluasi (monev). Masih terkait dengan administrasi bahwa supervisi, kepemimpinan, dan administrasi sebagai proses sosial pendidikan merupakan bagian yang tak bisa diabaikan. Sebagai administrator juga dituntut pengajar menjadi profesional dalam administrasi, juga dalam peranan teoritis dan praktis administrasi, serta tetap tenaga fungsional yang paham administrasi dalam era pembaharuan pendidikan.

Sebagai pelaku administrasi (admi-nistrator) maka ada beberapa prinsip dasar yang harus diperhatikan yaitu prinsip efisiensi, pengelolaan, pengutamaan tugas pengelolaan, kepemimpinan yang efektif, dan prinsip kerjasama. Selain itu juga berorientasi pada prinsip felksibelitas, efisien dan efektivitas, berorientasi pada tujuan kontinuitas, serta prinsip pendidikan seumur hidup. Lingkup administrasi pendidikan/sekolah menurut Daryanto (1998:26-27) meliputi : administrasi program pengajaran, administrasi murid/siswa, administrasi kepegawaian, administrasi keuangan, administrasi perlengkapan, administrasi surat menyurat, administrasi perpustakaan, administrasi pembinaan kesiswaan, dan administrasi hubungan sekolah dengan masyarakat. Bila administrasi itu diterapkan di dalam dunia pendidikan tinggi tentunya pendapat di atas dapat dirujuk dengan menyesuaikan pada kondisi pelaksanaan administrasi pendidikan pada tingkat pendidikan tinggi.

Berbeda dengan pendapat Subroto (1984) bahwa komponen administrasi pendidikan mencakup administrasi kurikulum, personil, murid, tata usaha, sarana pendidikan, dan hubungan sekolah dengan 
masyarakat. Ada penekanan bahwa tenaga pengajar juga sebagai pelaku administrasi pendidikan yang dinamai administrator. Dalam hal ini sebagai administyrator yang terampil dan andal. Kemudian ada pemimpin (leader) sebagai pengendali, pengarah, penanggung jawab, pelaku adminsitarasi pendidikan dalam peran sebagai administrator, sekaligus juga pemimpin sebagai pengawas (supervisor). Maka dari itu dalam dunia pendidikan tinggi bahwa pengajar itu memerankan dua fungsi yakni profesional dalam administrasi (adminsitrator) serta profesional dalam mengelola dan memerankan pengawasan yang profesional juga (supervisor). Cepat atau lambat jika kedua peran itu telah digeluti sebagai tugas dengan profesional maka tiba gilirannya sebagai orang top dalam pengelolaan adminsitrasi pendidikan tinggi yakni sebagai pemimpin (leader).

\section{Keterampilan Menggunakan Media Pendidikan}

Menurut Oemar Hamalik (1989:5-6) bahwa pengetahuan dan pemahaman tentang media pendidikan serta keterampilan memilih dan menggunakan media pendidikan dinyatakan yakni a) media sebagai alat komunikasi guna lebih mengefektifkan proses belajar mengajar, b)fungsi media dalam rangka mencapai tujuan pendidikan, c) tentang proses-proses belajar, d) hubungan atara metode mengajar dan media pendidikan, e) nilai atau manfaat media pendidikan dalam pengajaran, f) memilih dan menggunakan media pendidikan, g) berbagai jenis alat dan teknik media pendidikan, h) media pendidikan dalam setiap mata pelajaran, i) usaha inovasi dalam media pendidikan, dan lain-lain. Dalam pemilihan media pendidikan kriterianya yakni : a) tujuan mengajar, b) bahan pelajaran, c) metode mengajar, d) tersedianya alat yang dibutuhkan, e) jalan pelajaran, f) penilaian hasil belajar, g) pribadi guru, h) minat dan kemampuan siswa, i) situasi pengajaran yang sedang berlangsung.

Kemudian keterampilan membuat media pendidikan (Oemar Hamalik, 1989:7) syaratnya adalah 1) rasional, sesuai dengan akal dan mampu dipikirkan oleh kita, 2) ilmiah, sesuai dengan perkembangan akal dan mampu dipikirkan oleh kita, 3 ) ekonomis, sesuai dengan kemampuan pembiayaan yang ada, dan 4) praktis, dapat digunakan dalam kondisi praktek di sekolah dan bersifat sederhana. Jadi dengan pendapat di atas bahwa penggunaan, pemilihan, serta bagaimana membuat media pendidikan itu sudah jelas ketentuannya. Tinggal sekarang bagi pengajar (dosen) dapat menyesuaikan dengan kondisi dan situasi pada masing-masing tempat pembelajaran dan pengajaran. Apapaun kriteria mengenai media itu pada umumnya selalu ada alasan klasik yakni terbatasnya dana dan kurangnya kemampuan pengajar dalam memanfaatkan media yang ada.

Pandangan Nana Sudjana dan Ahmad Rivai (2002:1) bahwa metode mengajar dan media pengajaran sebagai alat bantu mengajar. Sedangkan penilaian adalah alat untuk mengukur atau menentukan taraf tercapai tidaknya tujuan pengajaran. Media pengajaran meliputi media grafis, gambar fotografi, media proyeksi, media audio, media tiga dimensi (sesuai dengan bahan, materi, dan pemanfaatan media secara variasi lebiah dari satu media), dan lingkungan sebagai media pengajaran (menggunakan lingkungan sebagai media murah dan bermanfaat, seperti lapangan, museum, pura, lingkungan desa, dan sebagainya). Dinyatakan bahwa media grafis terdiri atas a) bagan, b) diagram, c) grafik, d) poster, e) kartun, dan f) komik Nana Sudjana dan Ahmad Rivai (2002:27). Media proyeksi seperti overhead proyector, slide dan filmstrip. Media audio meliputi media perekaman suara dan yang sejenis seperti tape recorder, radio, TV, da sebagainya.

Menurut Sadiman dkk. (1986:209-210) bahwa peralatan media pendidikan terdiri atas peralatan proyeksi (optik) seperti overhead proyector (OHP), microform reader, proyektor film rangkai (film strip projector), proyektor film bingkai (slide projector), proyektor film gelang (film loop projector), proyektor film (motion ficture projector), dan peralatan elektronik seperti radio perekam kaset audio (radio cassette recorder), penalaradio (tuner) perekam pita audio (open reel tape recorder), perekam kaset audio (cassette recorder), amplifier, loudspeaker, perekam kaset audio sinkron (cassette synchrocorder), perekam pita video(video tape recorder), perekam kaset video (video cassette recorder), piringan video (video disc), sambang video (video cartridge), video monito, dan proyektor video. Jadi media pendidikan juga sangat menentukan terhadap keberhasilan peserta didik dan pengajar dalam proses pembelajaran dan pengajaran. Maka dari itu bagi pengajar yang baik perlu memilih dan memanfaatkan media pendidikan yang murah, tepat, dan efektif.

\section{Keterampilan Metodik dan Didaktik}

Keterampilan metodik dan didaktik bagi dosen adalah sangat penting, oleh karena keterampilan ini sangat menentukan keberhasilannya dalam melaksanakan tugas pengajaran atau dalam memberikan kuliah. Terkait dengan metodik bahwa pengajar harus tahu dimana posisinya di kelas, bagaimana sikap dan gayanya, serta metode apa yang tepat digunakan dalam memberikan kuliah. Ada 
beberapa metode mengajar, antara lain : metode ceramah, tanya jawab, diskusi, pemberian tugas, resitasi (perpaduan metode pemberian tugas dengan pelaporan hasil tugas), demonstrasi, eksperimen, sisodrama dan bermain peran, bekerja dalam kelompok, metode proyek, problem solving, karyawisata, film-strips, dan metode manusia sumber/ resource people( Roestiyah, 1986:67). Metode mengajar mana yang digunakan itu tergantung materi dan keterampilan dari dosen itu sendiri. Sedangkan keterampilan didaktik adalah keterampilan pengajar untuk dapat mengenali peserta didik secara baik dan penuh interaktif.

Berkenaan dengan sikap dan gaya pengajar menurut Roestiyah NK (1992:41-43) antara lain : 1) suasana penggambaran temperamen, 2) mengadakan kontak dengan murid berupa cerita, pertanyaan, diskusi, dsbnya, 3) cara menarik perhatian, 4) bersikap antusias terhadap materi perlajaran yang diberikan di kelas, 5) menghargai dirinya, 6) bicaranya jelas, 7) memperhatikan sifat-sifat khas peserta didik, 8) berpengetahuan dan memberikan perlindungan, 9) menghindari kekasaran dan suka menghina, 10) kerja sama yang baik, 11) saling berkorelasi dengan vak lain, 12) tidak pilih kasih, dan 13) jauhi ketidaktelitian dan kemalasan.

Adapun keterampilan didaktik adalah keterampilan yang terkait dengan sociometry yakni bagaimana mengenali peserta didik secara mendalam, memperhatikan, melakukan hubungan atau berteman secara simpati terhadap peserta didik. Untuk bisa mengenali karakter peserta didik adalah menjadi kewajiban penting bagi pengajar, tidak saja dapat menyusun tes yang baik, bergaul secara simpati, menerapkan tata tertib atau siasat, tetapi yang utama juga adalah adanya usaha-usaha pengajar melakukan keteladanan setiap hari, melakukan hal yang menyenangkan peserta didik, serta menghindari perilaku yang tidak menyenangkan peserta didik. Kapan pantas diberikan ganjaran dan kapan saatnya diberikan hukuman yang pantas dengan pertimbangan yang matang tanpa adanya sikap emosional.

\section{Keterampilan Mengelola Kelas}

Keterampilan mengelola kelas ada dipaparkan oleh EC Wragg dengan judul 'Pengelolaan Kelas', oleh Michael Marland dengan judul 'Seni Mengelola Kelas, Tugas dan Penampilan Seorang Pendidik', serta oleh Hadari Nawawi berjudul 'Organisasi Sekolah dan Pengelolaan Kelas'. Pengajar memang dituntut memiliki beragam keterampilan. Tidak saja menguasai ilmu pengetahuan dan teknologi, tetapi juga termasuk paham, cermat, arif, serta terampil dalam mengelola kelas. Ada apa dibalik perlunya pengajar memiliki keterampilan mengelola kelas tersebut. Jawabannya adalah agar tujuan pendidikan tersebut mencapai hasil yang maksimal yakni terwujudnya peserta didik yang cerdas, cekatan, terampil, berwawasan luas, bermoral, bertanggung jawab, serta menjadi kader bangsa Indonesia yang siap menjadi penerus generasi tuanya.

Berkenaan dengan pengelolaan kelas bahwa ada dua prinsip yang perlu diperhatikan, yakni : 1) pengelolaan kelas adalah segala sesuatu yang dilakukan guru agar anak-anak berpartisipasi aktif dalam kegiatan belajar mengajar, bagaimanapun caranya dan bentuknya; 2) ada berbagai cara untuk menciptakan keadaan dimana anak-anak berpartisipasi aktif dalam kegiatan belajar (EC Wragg, 1996:8). Pendapat ini menggugah para pengajar/ dosen untuk dapat membangkitkan aktivitas dan kreativitas peserta didik dalam mengikuti pembelajaran di kelas. Tidak ada alasan bagi pengajar untuk tidak mengaktifkan peserta didiknya pada saat memberikan kuliah. Atau jangan sampai hanya pengajar yang aktif sendiri, sedang peserta didik tinggal diam atau lain-lain tanpa ada peran sedikitpun. Jika hal itu terjadi, maka otomatis suasana kelas menjadi pasif dan dapat dikatakan suasananya mati. Oleh karena itu peran kedua pihak (mahasiswa dan pengajar) harus terjadi dan berinteraksi satu sama lain.

Menurut Michael Marland (1990:8) bahwa keberhasilan seorang guru di dalam mendidik muridnya, bukan hanya bergantung pada kepribadiannya yang menawan dan pengajaran yang impresif. Mata pelajaran apa saja yang diberikan, dengan menggnakan metode manapun, seorang guru tidak bekerja seorang diri. Dia adalah bagian dari suatu tim. Pengelolaan tim tersebut di suatu sekolah lanjutan agar bermanfaat bagi murid-muridnya, mempunyai seni yang tersendiri. Tiap guru wajib menguasai seni tersebut. Dan hal yang paling melegakan, ialah seni itu dapat dipelajari, dipraktekkan serta dikembangkan. Seni mengelola kelas bukan bakat alamiah. Dan kalau berhasil dalam melaksanakannya, guru dan murid akan lebih menikmati saat-saat mereka berada di sekolah.

Pendapat di atas perlu dicamkan dengan baik bahwa mengelola kelas adalah seni bagi pengajar. Juga mengelola kelas itu bukan bakat alamiah. Mengelola kelas itu bisa dipelajari dan dipraktekkan agar antara mahasiswa dan pengajar menjadi betah di kelas serta berhasil dalam pembelajaran dan pengajaran. Maka dari itu seni mengelola kelas adalah hal yang penting untuk dipelajari sehingga bisa menjadi terampil dalam mengelola kelas. Misalnya 
memberikan perhatian yang sama kepada para mahasiswa jika di kelas, menggunakan media tepat waktu, melakukan komunikasi dua arah, melakukan kebiasaan yang baik di kelas, mengaktifkan peserta didik, tidak terlalu melucu, penyajian yang menarik dan menyasar, dan yang lainnya guna menumbuhkan suasana kelas yang hidup, aktif, serta bergairah.

\section{Keterampilan Evaluasi Pendidikan}

Keterampilan evaluasi pendidikan adalah satu keterampilan bagi pengajar atau dosen untuk dapat melakukan tes atau penilaian terhadap keberhasilan peserta didik dalam mengikuti perkuliahan selama kurun waktu selama satu semester atau sesuai jadwal yang telah ditentukan. Keterampilan ini merupakan keahlian prinsip bagi dosen. Oleh karena materi sajian dalam perkuliahan tersebut harus diketahui hasilnya. Apakah sudah dapat dipahami dan diterapkan atau belum? Dengan pelaksanaan evaluasi pendidikan tersebut, maka dapat diukur tingkat keberhasilan peserta didik maupun pengajar selama kurun waktu yang telah ditentukan. Paling tidak ada ujian tengah semester (UTS) atau mid test dan ujian akhir semester (UAS) atau final test.

Mengenai jenis tes dan bentuk tes hasil belajar menurut Mudjijo (1995:29-30) yakni 1) tes lisan (oral test), 2) tes tertulis (written test), 3) tes tindakan atau perbuatan (performance test). Dalam tes tertulis dapat digunakan beberapa bentuk butir soal, yaitu : 1) tes bentuk uraian (essay test) yang terdiri atas tes uraian bebas dan terikat, 2) tes bentuk obyektif (obyektive test) yang terdiri atas butir soal benar salah (true false), pilihan berganda (multiple choise), isian (completion), jawaban singkat (short answer), dan menjodohkan (matching). Penggunaan jenis dan bentuk tes disesuaikan dengan kawasan (domain) perilaku peserta didik yang hendak diukur. Kawasan yang diukur seperti ranah kognitif mencakup : pengetahuan, pemahaman, penerapan, analisis, sintesis, dan evaluasi. Ranah afektif mencakup : penerimaan, partisipasi, penilaian/penentuan sikap, organisasi, dan pembentukan pola hidup. Sedangkap ranah psikomotorik mencakup : persepsi, kesiapan, gerakan terbimbing, gerakan terbiasa, gerakan kompleks, penyesuaian pola gerakan, dan kreativitas.

Kemudian yang perlu diperhatikan adalah bagaimana melakukan tes atau evaluasi pendidikan dengan ciri-ciri suatu tes hasil belajar yang baik. Menurut Gronlund NE dalam Mudjijo (1995:40) bahwa sebuah program pengevaluasian harus memiliki beberapa karakteristik umum tertentu. Karakteristik-karakteristik yang paling penting dapat dikelompokkan di bawah judul validity (validitas), reliability (keterandalan), dan usability (pemakaian).

\section{Keterampilan Memberikan Penguatan}

Keterampilan ini tergolong langka diterapkan di kelas. Hal ini disebabkan oleh karena adanya keterampilan yang kurang dipahami dari pengajar itu sendiri. Mengapa pengutan itu penting dilakukan oleh pengajar.Oleh karena keterampilan memberikan penguatan merupakan cara yang positif untuk menggugah semangat belajar peserta didik. Selain itu untuk dapat meyakinkan kepada para peserta didik bahwa suatu materi perkuliahan wajib diikuti secara utuh, komprehensif, tekun, rajin, sempurna, dan penuh tanggung jawab. Bilamana hal itu terjadi dalam kelas, sangat wajar dan pantas pengajar itu memberikan penguatan secara spontan kepada peserta didiknya. Misalnya dengan sikap ramah, penampilan yang riang gembira, memberikan pujian, memberikan nuilai yang bagus, memberikan salam serta hal lainnya yang mendorong semangat belajar peserta didik tersebut.

Sebaliknya jika kondisi belajar peserta didik nampak loyo, kurang bergairah, tidak ada perhatian kepada pengajarnya, maka dalam hal ini perlu ada perhatian dan penguatan yang lebih intensif, lebih seirus, serta lebih spontan lagi oleh pengajar. Jika hal ini dibiarkan, maka suasana kelas menjadi adem ayem, pasif, dan tidak bersemangat. Pengajar perlu membuat selingan dan memberikan penguatan yang bersifat konstruktif, persuasif, dan dengan pendekatan variatif, yakni antara penyajian materi kuliah dan pemberian penguatan harus diseimbangkan. Yang terpenting ada gairah belajar menjadi lebih baik. Materi kuliah bisa nyambung dan penguatan turutsebagai pembangkit semangat belajar. Disinilah pentingnya keterampilan memberikan penguatan itu perlu ditampilkan oleh pengajar.

\section{Keterampilan Membimbing Peserta Didik}

Membimbing peserta didik merupakan bagian penting sebagai keterampilan bagi pengajar. Membimbing peserta didik adalah tugas yang tidak gampang. Sama halnya dengan mengelola kelas itu perlu seni. Dalam membimbingpun perlu seni. Bila peserta didik yang dibimbing terlalu banyak, maka dirasakan ada kesulitan bagi pengajar. Atau sebaliknya jika yang dibimbing terlalu sedikit, jangan menganggap bahwa membimbing itu sebagai tugas yang enteng. Membimbing perlu keuletan, kesinambungan, ketekunan, serta tugas yang tegolong rutin. Selanjutnya pengembangan profesi dosen meliputi empat kompetensi, yaitu:

1. Kompetensi pedagogis atau kemampuan dosen mengelola pembelajaran 
2. Kompetensi kepribadian atau standar kewibawaan, kedewasaan, dan keteladanan

3. Kompetensi profesional atau kemampuan dosen untuk menguasai content dan metodologi pembelajaran

4. Kompetensi sosial atau kemampuan dosen untuk melakukan komunikasi sosial, baik dengan mahasiswa maupun masyarakat luas.

Berdasarkan beberapa pendapat tersebut, dapat dirumuskan setidaknya tujuh bidang kompetensi berikut strategi pengembangannya melalui programprogram tertentu yang mendukung peningkatan bidang-bidang kompetensi tersebut. Tujuh bidang kompetensi yang dimaksud adalah:

\section{Pengembangan Kompetensi Pedagogis}

Kompetensi pedagogis atau kemampuan dosen mengelola pembelajaran merupakan tulang punggung keberhasilan proses pendidikan di perguruan tinggi. Kompetensi pedagogis ini terkait dengan cara mengajar yang baik dan tepat, sehingga proses pembelajaran dapat berjalan dengan lancar dan efektif. Seorang dosen, selain harus memiliki kepakaran di bidang keilmuannya, juga harus menguasai teori-teori dan teknik pengajaran serta aplikasinya dalam proses pembelajaran di perguruan tinggi. Sebab itu, peningkatan kemampuan di bidang ini merupakan hal utama dalam pengembangan profesionalisme dosen.

Untuk meningkatkan kemampuan pedagogis ini, para tenaga dosen perlu diberikan pelatihan yang terkait dengan metode pengajaran di perguruan tinggi yang meliputi:

a. Metode Diskusi (Discussion Method). Metode ini lebih efektif dari metode ceramah, karena diskusi menuntut mental dan pikiran serta tukar menukar pendapat. Selain itu, diskusi juga lebih komunikatif, mampu menjelaskan hal-hal yang masih semu, dan mampu mengungkap tingkat keaktifan setiap mahasiswa.

b. Metode Studi Kasus (The Case Method). Metode ini relevan terutama untuk program studi yang menekankan penerapan suatu hukum terhadap suatu kasus, misalnya di fakultas hukum atau fakultas pertanian, dan lain-lain. Suatu kasus dijadikan bahan untuk diskusi mahasiswa di bawah bimbingan dosen.

c. Metode Tutorial (Tutorial Method). Metode ini berupa penugasan kepada beberapa mahasiswa tentang suatu objek tertentu, lalu mereka mendiskusikannya dengan pakar di bidangnya untuk memastikan validitas pemahaman mereka tentang objek tersebut.

d. Metode Tim Pengajar (Team Teaching Method). Salah satu bentuk dari metode ini adalah sekurang-kurangnya dua orang dosen mengajar satu materi kuliah yang sama dalam waktu yang sama pula, namun dengan pokok bahasan yang saling melengkapi.

e. Metode Ceramah. Metode ini muncul paling awal dan banyak digunakan terutama jika mahasiswa dalam satu kelas sangat banyak.

\section{Pengembangan Kompetensi Teknik Informasi}

Perkembangan teknologi informasi yang demikian cepat merupakan tantangan baru bagi para praktisi pendidikan, termasuk dosen. Para pakar pendidikan memandang bahwa penguasaan para dosen terhadap teknologi informasi sangat berpengaruh terhadap kesuksesannya dalam mengelola pembelajaran di perguruan tinggi.

Sebab itu, para dosen perlu diberikan pelatihan penggunaan berbagai macam teknologi informasi yang tersedia saat ini, mulai dari komputer, televisi, telepon, video conference, hingga dunia internet. Pengembangan kemampuan memanfaatkan teknologi informasi ini dibutuhkan dalam perencanaan pendidikan, terutama yang terkait dengan analisis, desain, implementasi, manajemen, hingga evaluasi instruksional pendidikan. Untuk pengembangan kemampuan teknologi informasi ini dibutuhkan beberapa hal berikut:

a. Ketersediaan fasilitas teknologi berikut perlengkapannya, baik berupa komputer, video, proyektor, perlengkapan internet, dan sebagainya.

b. Ketersediaan isi serta bahan-bahan terkait metode penggunaan teknologi informasi tersebut untuk mendukung metode pengajaran dan pelaksanaan kurikulum pendidikan.

c. Penyelenggaraan pelatihan bagi para dosen tentang cara penggunaan alat-alat teknologi informasi tersebut, sehingga pada saatnya mereka dapat mengajarkannya juga kepada para mahasiswa. Dengan demikian, proses pembelajaran akan berlangsung lebih efektif dan produktif.

\section{Pengembangan Kompetensi Manajemen/ Administrasi}

Sistem manajemen perguruan tinggi berbeda dengan manajemen di lembaga-lembaga lainnya. Di lingkungan perguruan tinggi terdapat komunitas berbeda yang saling terkait, yaitu mahasiswa, dosen, 
pegawai, dan para pekerja. Mereka semua diatur oleh pimpinan. Demikian pula model manajemen yang diterapkan di sebuah perguruan tinggi mengalami perubahan berdasarkan perkembangan perguruan tinggi tersebut. Manajemen di perguruan tinggi yang baru didirikan berbeda dengan manajemen di perguruan tinggi yang sudah maju.

Dengan asumsi ini, para dosen sebagai bagian utama dari perguruan tinggi, sesungguhnya dibutuhkan untuk terlibat secara langsung dalam mengelola perguruan tinggi, baik pada level pimpinan universitas, fakultas, jurusan, program studi, maupun tim-tim yang dibentuk khusus untuk tujuan tertentu. Sebab itu, pengembangan kemampuan manajemen sangat penting bagi para dosen. Jika mereka diharapkan untuk memberikan kontribusi signifikan dalam pengelolaan perguruan tinggi, maka kemampuan administrasi dan manajemen mereka perlu terus ditingkatkan.

Untuk menunjang kemampuan manajemen para dosen, perlu diberikan pelatihan intensif dan berkesinambungan mengenai manajemen/ administrasi umum, administrasi/manajemen perguruan tinggi, perumusan strategi pendidikan, dasar-dasar perencanaan pendidikan, manajemen kurikulum, pengambilan keputusan, administrasi/ manajemen kepegawaian, manajemen sumber daya manusia, manajemen konflik, penyusunan program berikut pelaksanaannya, hubungan masyarakat, dan sebagainya.

\section{Pengembangan Kompetensi Kurikulum}

Kurikulum merupakan fundamen yang sangat penting untuk mencetak mahasiswa yang berkualitas tinggi. Kurikulum yang baik adalah kurikulum yang kandungannya memperhatikan kemampuan peserta didik serta mampu mendorong kemampuan mereka menjadi daya kreatif dan inovatif. Di sinilah salah satu peran penting para dosen. Mereka adalah kunci pembuka pengembangan kurikulum, karena merekalah yang paling menguasai secara mendalam masing-masing disiplin keilmuan.

Namun penguasaan terhadap suatu disiplin ilmu bukanlah satu-satunya ukuran kesuksesan profesi seorang dosen. Mereka juga dituntut mampu merumuskan kurikulum yang dapat menciptakan para sarjana dengan prestasi akademik yang tinggi, berperilaku terhormat, serta berbudi baik. Karena itu, para dosen perlu diberikan kesempatan untuk mengikuti perkembangan terbaru bidang ilmu yang digelutinya agar mereka dapat merumuskan kurikulum juga berdasarkan perkembangan terbaru. Mereka juga perlu didukung secara moral dan dana untuk menyelenggarakan berbagai kegiatan yang bertujuan menciptakan kurikulum terbaik. Untuk meningkatkan kemampuan tenaga dosen dalam merumuskan kurikulum, perlu diselenggarakan kegiatan berupa:

a. Pertemuan, baik seminar, lokakarya, maupun lainnya, yang tujuannya memperbarui pengetahuan para dosen tentang perkembangan terbaru di bidang disiplin ilmu tertentu. Pengetahuan itu akan menjadi bekal mereka dalam merumuskan kurikulum yang baik.

b. Pelatihan cara menyusun rencana materi pengajaran. Tugas ini terbilang sulit terutama bagi para dosen baru. Tetapi ia sangat penting karena dapat membantu dosen mengatur kisikisi pengajarannya, seperti tujuan, isi, model, strategi, evaluasi dan referensi pengajaran.

c. Pelatihan cara merancang rencana materi pengajaran berdasarkan tujuan dan target dari masing-masing materi pelajaran, serta unsurunsur rencana pengajaran.

d. Pertemuan, baik seminar, lokakarya, maupun lainnya, yang diadakan setelah pembaruan kurikulum dengan maksud menyatukan persepsi di antara para dosen tentang metode dan cara yang efektif untuk menjalankan kurikulum tersebut agar berhasil seperti yang diharapkan. Dengan pertemuan tersebut akan terjadi harmoni antara kurikulum baru dengan perkembangan pengetahuan para dosen.

\section{Pengembangan Kompetensi Ilmiah (Riset dan Publikasi)}

Salah satu tugas pokok perguruan tinggi adalah mengembangkan ilmu pengetahuan. Tugas tersebut direalisasikan melalui pengkajian dan riset-riset ilmiah yang dilakukan oleh komunitas akademik yang terdapat di dalamnya, terutama para dosen. Dengan demikian tugas para dosen tidak terbatas pada kegiatan mengajar saja. Mereka juga dituntut terus melakukan riset-riset ilmiah secara serius dalam bidang yang digelutinya agar dapat menyumbang dan memperkaya ilmu pengetahuan. Program yang perlu dilaksanakan untuk mengembangkan produktivitas ilmiah para dosen adalah:

a. Pelatihan metodologi dan etika penelitian ilmiah dengan segala aspeknya terutama yang terkait dengan disiplin ilmu masingmasing kelompok dosen.

b. Penyediaan sarana dan fasilitas yang dibutuhkan untuk penelitian, seperti komputer, laboratorium, perpustakaan yang lengkap, dan sebagainya

c. Pengaturan beban jam mengajar para dosen agar mereka mempunyai kesempatan untuk menulis buku, menghadiri seminar, atau melakukan semua proses penelitian 
d. Mendukung dana atau membantu menghubungkan dengan lembaga yang dapat membiayai proyek penelitian mereka.

\section{Pengembangan Kompetensi Evaluasi}

Perguruan tinggi adalah salah satu lembaga pendidikan yang menjadikan evaluasi sebagai salah satu cara mengembangakan kualitasnya. Hal itu karena evaluasi yang benar merupakan salah satu cara terbaik untuk mengembangkan proses pembelajaran. Dengan evaluasi yang benar akan diketahui secara objektif kelebihan dan kekurangan sebuah sistem pembelajaran sehingga program pengembangan ataupun perbaikan dapat dirumuskan dengan tepat. Begitu pula, melalui evaluasi akan diketahui sejauh mana sebuah perguruan tinggi dapat mewujudkan tujuan dan target yang telah dicetuskan saat pendiriannya. Sebab itu, untuk mengembangkan mutu perguruan tinggi, dibutuhkan evaluasi yang benar dan akurat terhadap dosen, kurikulum, sistem manajemen, mahasiswa, dan elemen-elemen pokok lainnya

Dalam proses evaluasi pendidikan di perguruan tinggi ini, para tenaga dosen memiliki peran yang sangat penting, karena merekalah yang berhak menilai dan menimbang kualitas pembelajaran yang mereka berikan atau yang berlaku di universitas tempat mereka mengabdikan diri. Selain sebagai pihak yang mengevaluasi, para dosen juga merupakan objek evaluasi. Kinerja mereka sebagai tenaga pengajar juga dinilai untuk diperbaiki atau diberi penghargaan berupa kenaikan pangkat. Karena itu, untuk mengembangkan kemampuan dosen dalam melakukan evaluasi pendidikan, perlu diadakan:

a. Pelatihan tentang filosofi dan teori-teori evaluasi modern dalam bidang pendidikan agar dosen menyadari bahwa evaluasi merupakan bagian yang inheren dan penting dalam proses pendidikan. Selain itu agar mereka memahami mekanisme evaluasi pendidikan yang benar.

b. Pelatihan tentang teknik-teknik dan modelmodel evaluasi untuk kemudian menentukan metode evaluasi yang kuratif demi perbaikan dan pengembangan program-program akademis selanjutnya

c. Pelatihan tentang cara menyusun rencana evaluasi dan mekanisme implementasinya, baik untuk menilai kinerja dosen sendiri maupun tingkat capaian mahasiswa secara objektif, menetapkan standar dan kriteria, serta melakukan pengujian-pengujian terhadap pelaksanaan program-program akademis di perguruan tinggi.

\section{Pengembangan Kompetensi Personal}

Di era globalisasi seperti sekarang ini, di mana dunia berubah begitu cepat, perguruan tinggi dihadapkan pada tantangan yang lebih kompleks. Berkat kemajuan sains dan teknologi, metodologi pendidikan juga melaju pesat dengan bertumpu pada metode serta teknologi mutakhir. Di tengah situasi ini, tidak ada jalan lain bagi perguruan tinggi kecuali memulai merumuskan program pengembangan komprehensif, termasuk peningkatan profesionalisme para dosennya.

Sebagai salah satu pilar utama perguruan tinggi, tingkat kemampuan dan integritas personal para dosen menjadi salah satu faktor yang menentukan optimalisasi proses pendidikan dan pengajaran di perguruan tinggi. Jika para dosen tidak mampu beradaptasi dengan perkembangan ilmu pengetahuan serta perubahan metode atau teknologi pendidikan yang berubah cepat, maka yang terancam bukan hanya masa depan para lulusannya, tetapi juga eksistensi dan masa depan perguruan tinggi tersebut. Karena itu, dosen dituntut untuk terus meningkatkan kemampuan ilmiah dan kepribadiannya melalui berbagai upaya yang mungkin dilakukannya.

Sebenarnya tidak ada program khusus untuk mengembangkan integritas personal para dosen. Setiap dosen berhak menentukan program apa yang dibutuhkan untuk mengembangkan profesionalismenya. Semua program pengembangan yang telah dijelaskan sebelum ini misalnya, pada dasarnya merupakan program-program yang mengacu pada pengembangan integritas personal dosen. Seorang dosen dapat memilih salah satunya atau menambahkan program lain yang dipandangnya relevan untuk dirinya.

Meski demikian, beberapa pakar pendidikan mengemukakan program-program yang perlu dilakukan para dosen dalam rangka melejitkan potensi dan kemampuan dirinya. Program-program ini mendorong para dosen untuk:

a. Sesering mungkin berpartisipasi dalam seminar atau konferensi yang terkait displin keilmuannya, baik di tingkat nasional maupun internasional.

b. Melakukan studi komparatif ke perguruan tinggi atau lembaga pendidikan lainnya di dalam dan luar negeri untuk mengetahui serta belajar dari pengalaman lembaga-lembaga pendidikan lain tersebut

c. Berusaha membentuk semacam asosiasi para pakar atau organisasi profesi di bidang keilmuannya untuk kemudian menggelar kegiatan-kegiatan ilmiah serta menerbitkan jurnal-jurnal ilmiah 
d. Menyusun program-program pelatihan dan proyek-proyek penelitian berskala nasional dan internasional bekerjasama dengan lembaga-lembaga ilmiah di dalam atau di luar negeri.

e. Memanfaatkan kerjasama yang sudah terjalin dengan lembaga-lembaga nasional maupun internasional dalam rangka internasionalisasi perguruan tinggi dan pengabdian terhadap kemanusiaan secara umum.

f. Terkait dengan etika pribadi, seorang dosen dituntut untuk mencintai kebenaran dan selalu berusaha menemukan kebenaran-kebenaran baru, toleran terhadap perbedaan pendapat, adil, jujur serta bertanggung jawab.

Program-program tersebut lebih banyak menekankan pada upaya pribadi dosen, karena sejatinya program pengembangan integritas personal dosen tidak harus selalu mengacu pada program yang disiapkan perguruan tinggi, tapi juga membutuhkan inisiatif internal dan usaha keras dari dalam diri masing-masing dosen.

\section{PENUTUP}

Perkembangan dalam dunia pendidikan, termasuk juga kemajuan ilmu pengetahuan dan teknologi dalam era global menuntut perhatian pemerintah RI untuk terus berbuat banyak dalam menata dinamika pendidikan tersebut. Salah satu produk tentang pendidikan di Indonesia yang paling anyar adalah dengan dikeluarkannya UU tentang Guru dan Dosen No. 14 tahun 2005. Produk hukum tersebut mengisyaratkan kepada pengelola lembaga pendidikan dari tingkat pendidikan dasar sampai pendidikan tinggi, termasuk juga pendidikan tinggi agama Hindu untuk mempersiapkan tenaga dan sarana prasarana pendidikan yang berkualitas.

Mengelola pendidikan tinggi agama Hindu sesuai aturan dari pemerintah terutama Peraturan Presiden Nomor 1 tahun 2004, memberikan kesempatan emas kepada umat Hindu Indonesia untuk menimba pengetahuan agama Hindu pada lembaga pendidikan tinggi agama Hindu negeri. Lembaga pendidikan tinggi agama Hindu negeri ini sebagai harapan mulia umat Hindu Indonesia. Selain itu, diharapkan pula agar adanya kualitas tenaga pengelolanya (baik dosen dan pegawai), yang pada akhirnya melahirkan tamatan yang bermutu demi kemajuan pembinaan umat Hindu Indonesia ke depan.

Salah satu cita-cita Umat Hindu di Indonesia adalah memiliki perguruan tinggi bertaraf nasional dan internasional (world class university). Cita-cita ini membutuhkan kerja keras dari seluruh elemen perguruan tinggi untuk memperbaiki dan mengembangkan kualitas pembelajarannya. Salah satu program pengembangan yang seharusnya mendapat prioritas adalah pengembangan profesionalisme dosen sebagai elemen pokok perguruan tinggi. Pengembangan profesionalisme dosen ini sangat penting untuk meningkatkan mutu perguruan tinggi di Indonesia.

Program-program pengembangan profesi dosen sebagaimana telah diuraikan sebelum ini sesungguhnya merupakan bagian tak terpisahkan dari program pengembangan perguruan tinggi secara umum dan pengembangan IHDN Denpasar menjadi Universitas Hindu Negeri pada khususnya, karena keberhasilan dari program tersebut akan berpengaruh terhadap kualitas perguruan tinggi itu sendiri. Sebab itu, program-program tersebut perlu diimplementasikan secara teratur dan berkesinambungan agar betulbetul tercipta para dosen yang berkualitas tinggi dan mampu mendorong kemajuan perguruan tinggi. Pada tingkat praktik, sarana yang dapat digunakan untuk mengimplementasikan program-program pengembangan tersebut adalah:

1. Penyelenggaraan pendidikan dan pelatihan yang bertujuan menambah wawasan dan pengetahuan para dosen, baik yang terkait dengan disiplin ilmu yang ditekuninya maupun keahlian pedagogi dan kependidikan secara umum.

2. Pendirian lembaga atau pusat-pusat pengembangan ilmu pengetahuan dan profesi akademis, termasuk profesi dosen, yang prioritas kegiatannya terkait dengan pelaksanaan riset-riset ilmiah dan pelatihan peningkatan kompetensi akademis.

3. Kerjasama ilmiah dengan perguruan tinggi lain, baik berupa pertukaran dosen, riset bersama (join research), maupun program double degree. Kerjasama ilmiah ini juga bisa dilakukan antara perguruan tinggi dengan pusat-pusat penelitian, atau perusahaanperusahaan, baik di tingkat nasional maupun internasional.

Dengan usaha yang sungguh-sungguh dari perguruan tinggi Hindu untuk mengembangkan profesionalisme para dosennya, diharapkan akan tercipta para dosen yang mampu menjalankan tugasnya secara profesional, yaitu mencetak para ilmuwan dan tenaga ahli di berbagai bidang, mencerdaskan kehidupan bangsa dalam arti yang seluas-luasnya, serta mengembangkan pribadipribadi manusia Indonesia seutuhnya. 


\section{DAFTAR PUSTAKA}

Anonim, 2004. Undang-Undang Tentang Sisdiknas dan Peraturan Pelaksanaannya 2000-2004. Jakarta: CV:Tamita Utama.

Anonim, 2005. Strandar Nasional Pendidikan. Jakarta:Cemerlang.

Anonim, 2006. Undang-Undang Republik Nomor 14 Tahun 2005 Tentang Guru dan Dosen. Bandung:Citra Umbara.

Daryanto, 1998. Adminstrasi Pendidikan. Jakarta:Rineka Cipta.

Marland, 1990. Seni Mengelola Kelas, Tugas dan Penampilan Seorang Pendidik. Semarang:Dahara Prize.

Mudjijo, 1995. Tes Hasil Belajar. Jakarta:Bumi Aksara.

Nawawi, 1995. Organisasi Sekolah dan Pengelolaan Kelas. Jakarta PT Gunung Agung.
Roestiyah, 1986. Metodik Didaktik. Jakarta:PT Bina Aksara.

Sadiman, dkk. 1986. Media Pendidikan Pengertian, Pengembangan dan Pemanfaatannya. Jakarta:CV Rajawali.

Subroto, 1984. Dimensi-Dimensi Administrasi Pendidikan di Sekolah Yogyakarta:Bina Aksara.

Sudjana, Nana dan Ahmad Rivai, 2002. Media Pengajaran. Bandung:Sinar Baru Algensindo.

Sutisna, 1987. Administrasi Pedidikan Dasar Teoritis Untuk Praktek Prefesional. Bandung:Angkasa.

Tim Penyusun, 1994. Kamus Besar Bahasa Indonesia. Depdikbud dan Balai Pustaka Jakarta.

Wragg, EC. 1996. Pengelolaaan Kelas. Jakarta:PT Gramedia. 